\title{
Bayesian Estimation of qPCR and Bacterial Culture Accuracy for Detection of Bovine Coagulase-Negative Staphylococci from Milk and Teat Apex at Different Test Cut-off Points
}

Mahmmod, Y. S.; Svennesen, L.; Katholm, J.; Pedersen, Karl; Klaas, I. C.

Published in:

Journal of Applied Microbiology

Link to article, DOI:

10.1111/jam.14309

Publication date:

2019

Document Version

Peer reviewed version

Link back to DTU Orbit

Citation (APA):

Mahmmod, Y. S., Svennesen, L., Katholm, J., Pedersen, K., \& Klaas, I. C. (2019). Bayesian Estimation of qPCR and Bacterial Culture Accuracy for Detection of Bovine Coagulase-Negative Staphylococci from Milk and Teat Apex at Different Test Cut-off Points. Journal of Applied Microbiology, 127(2), 406-417. https://doi.org/10.1111/jam.14309

\section{General rights}

Copyright and moral rights for the publications made accessible in the public portal are retained by the authors and/or other copyright owners and it is a condition of accessing publications that users recognise and abide by the legal requirements associated with these rights.

- Users may download and print one copy of any publication from the public portal for the purpose of private study or research.

- You may not further distribute the material or use it for any profit-making activity or commercial gain

- You may freely distribute the URL identifying the publication in the public portal 
DR. YASSER MAHMMOD (Orcid ID : 0000-0002-1975-3454)

Article type : Original Article

Bayesian Estimation of qPCR and Bacterial Culture Accuracy for Detection of Bovine Coagulase-Negative Staphylococci from Milk and Teat Apex at Different Test Cut-off Points

Running headline: qPCR and Culture for non-aureus Staphylococci Diagnosis

\section{Y. S. Mahmmod ${ }^{1,2,3}{ }^{*}$, L. Svennesen ${ }^{1}$, J. Katholm ${ }^{4}$, K. Pedersen ${ }^{5,6}$, I.C. Klaas ${ }^{1,7}$}

${ }^{1}$ Department of Veterinary and Animal Sciences, Faculty of Health and Medical Sciences, University of Copenhagen, DK-1870 Frederiksberg C, Denmark

${ }^{2}$ Infectious Diseases, Department of Animal Medicine, Faculty of Veterinary Medicine, Zagazig University, 44511-Zagazig, Sharkia Province, Egypt

${ }^{3}$ IRTA, Centre de Recerca en Sanitat Animal (CReSA-IRTA), Campus de la Universitat Autònoma de Barcelona, 08193-Bellaterra, Barcelona, Spain (Current)

${ }^{4}$ DNA Diagnostic A/S, Voldbjergvej 14, 8240 Risskov, Denmark

5 National Veterinary Institute, Technical University of Denmark, 2800 Kongens Lyngby, Denmark

${ }^{6}$ National Veterinary Institute, SE-751 89 Uppsala, Sweden (Current)

${ }^{7}$ DeLaval International AB, Tumba, Sweden (Current)

This article has been accepted for publication and undergone full peer review but has not been through the copyediting, typesetting, pagination and proofreading process, which may lead to differences between this version and the Version of Record. Please cite this article as doi: 10.1111/jam.14309

This article is protected by copyright. All rights reserved. 


\title{
* Corresponding author
}

Yasser S. Mahmmod

IRTA, Centre de Recerca en Sanitat Animal (CReSA-IRTA, UAB), Campus de la Universitat Autònoma de Barcelona, 08193-Bellaterra, Barcelona, Spain (Current)

Email: yasser.mahmmod@irta.cat; yasser@sund.ku.dk

Mobile: 0034-612567320

ORCID: 0000-0002-1975-3454

\begin{abstract}
Aim: primarily to estimate the sensitivity (Se) and specificity ( $\mathrm{Sp}$ ) of the commercially available Mastit4 qPCR assay and bacterial culture (BC) for diagnosis of intramammary infections (IMI) and teat apex colonization (TAC) with coagulase-negative staphylococci (CNS) at different cut-offs for qPCR cycle threshold $(\mathrm{Ct})$ values using Bayesian latent class analysis (LCA). A secondary objective was to evaluate two cut-offs of BC for diagnosis of IMI and TAC with CNS.
\end{abstract}

Methods and Results: we randomly selected 13 to 20 cows with subclinical mastitis from 8 dairy herds. Teat skin samples and aseptically collected foremilk samples were collected from the right hindquarters $(n=149)$ for BC and qPCR analysis. The Se of qPCR was always higher than $\mathrm{BC}_{\mathrm{Se}}$ in diagnosis of IMI, however; the $\mathrm{Sp}$ of $\mathrm{BC}$ was higher than $\mathrm{qPCR}_{\mathrm{Sp}}$. $\mathrm{BC}_{\mathrm{Se}}$ and $\mathrm{BC}_{\mathrm{Sp}}$ showed no substantial difference between the tested BC cut-offs. In contrast to IMI, estimates of $\mathrm{BC}$ and $\mathrm{qPCR}$ in diagnosing $\mathrm{TAC}$ were different. $\mathrm{BC}_{\mathrm{Se}}$ was higher than $\mathrm{qPCR}_{\mathrm{Se}}$ at all tested cut-offs, however; $\mathrm{qPCR}_{\mathrm{Sp}}$ was higher than $\mathrm{BC}_{\mathrm{Sp}}$.

Conclusion: the overall performance of $\mathrm{qPCR}$ is higher than $\mathrm{BC}$ in the diagnosis of IMI however; the performance of BC is better than qPCR in diagnosis of TAC. The qPCR and BC are valid diagnostics for bovine IMI with CNS. Whereas for TAC, both techniques require further investigation to reduce the uncertainty of the true status of the quarter and teat skin.

This article is protected by copyright. All rights reserved. 
Significance and Impact of the Study: we reported, for the first time, the diagnostic performance of new mastitis technology (Mastit4 PCR) and culture for detection of CNS in milk and non-milk samples in dairy herds with automatic milking systems. Our findings will improve the interpretation of the test results of culture and qPCR assay and subsequently, will strengthen the control of IMI with CNS in dairy cows.

Keywords: bovine mastitis; non-aureus staphylococci; teat skin colonization; diagnostic test evaluation; sensitivity and specificity; latent class analysis

\section{Introduction}

Coagulase-Negative Staphylococci (CNS) are considered the most common cause of intramammary infections (IMI) in dairy cows (Piepers et al. 2007; De Visscher et al. 2016). In Denmark, Katholm et al. (2012) found staphylococci species including Staphylococcus aureus in $100 \%$ of the bulk tank milk samples from all 4,258 Danish dairy herds in 2009 using a commercial real-time qPCR analysis. Traditionally, CNS are considered as minor IMI pathogens in dairy cows. However, CNS that persist in the mammary gland have a high antimicrobial resistance capacity and moderately increase milk somatic cell count (Nobrega et al. 2018; Qu et al. 2019). Sørensen et al. (2010) estimated the economic losses due to IMI with CNS to be $€ 380$. Additionally, Bexiga et al. (2011a) found the average cost to be $€ 38.7$ for antimicrobial treated quarters with CNS subclinical mastitis. Beside its important role in causing IMI, CNS have the ability to colonize extra-mammary habitats such as teat apex and teat canal (Vanderhaeghen et al. 2014; Souza et al. 2016). Therefore, improving control measures including efficient diagnostic methods for identifying CNS IMI is vital for improving of udder health in dairy herds.

This article is protected by copyright. All rights reserved. 
DNA-based molecular diagnostics such as quantitative PCR (qPCR) assays are increasingly implemented as a routine method for mastitis control programs in the last few years in several countries (Nyman et al. 2016; Timonen et al. 2017; Soltau et al. 2017). However, conventional bacterial culture $(\mathrm{BC})$ is still regarded as the gold standard for mastitis diagnosis and implemented in routine diagnostic by most laboratories worldwide (Persson Waller 2013). Despite that, standard BC may show few limitations such as time-consuming, and limited precision in bacterial species identification (Ruegg 2009). Therefore, genotypic identification systems became an acceptable diagnostic tool for most of the mastitis pathogens to overcome misclassification based on phenotypic patterns.

Recent research showed that the different CNS species have different species-specific characteristics in epidemiology and adaptation (Piessens et al. 2012). CNS species can be classified according to their different characteristics into udder-adapted, opportunistic and environmental CNS (Supré et al. 2011; Piessens et al. 2012) or as virulent, protective and of no importance (Wilson et al. 2004; Schukken et al. 2009). CNS species colonizing teat apex could play a role in relation to IMI, e.g. by being a risk factor or having a protective role. Therefore, it is important to have highly accurate diagnostic tools to identify CNS from teat skin as well as milk samples to identify the distribution of CNS species in extramammary and intramammary sites and subsequently, their potential as causative of IMI (Mahmmod et al. 2018a, b). In this regard, the application of molecular techniques would provide sensitive, quantitative and large-scale routine mastitis diagnosis tools to evaluate the effect of colonization on the probability of IMI (Svennesen et al. 2019).

The diagnostic accuracy of PCR-based methods has shown high sensitivity (Se) and specificity ( $\mathrm{Sp}$ ) in detection of bacteria in milk, compared to conventional BC for many udder pathogens such as S. aureus, Streptococcus agalactiae and Streptococcus uberis (Cederlof et al. 2012; Mahmmod et al. 2013a,b; Nyman et al. 2016; Steele et al. 2017; Holmøy et al. 
2018). Using latent class analysis (LCA) approach, Nyman et al. (2016) estimated the Se and Sp of PCR (PathoProof ${ }^{\mathrm{TM}}$ PCR) and BC for identification of IMI with CNS in Swedish dairy herds, although that PCR test type did not directly measure CNS but all Staphylococcus species that then were evaluated against the $S$. aureus content. However, the estimates of the qPCR assay were based on composite, non-aseptically collected milk samples from milk test day (DHI) with the risk of false positive results due to contamination or carry-over effects (Mahmmod et al. 2014, 2017). Using the "Gold standard" approach, Dohoo et al. (2011) evaluated several definitions for classifying a quarter as having, or not having an IMI with CNS by comparing the results from a single culture to a gold standard diagnosis based on a set of three milk samples. However, a major drawback of using imperfect reference test is that the index test's characteristics are subject to selection and information bias (Dohoo 2014; Haine et al. 2018).

In the absence of a reasonable reference test or true gold standard for detection of CNS with known Se and Sp, Bayesian LCA provides an invaluable option for the estimation of Se and Sp of two or more tests without any assumption about the underlying true disease status of each subject (Hui and Walter 1980). To the best of our knowledge, there is no available literature that quantifies the diagnostic performance of $\mathrm{BC}$ and real-time $\mathrm{qPCR}$, for the detection of CNS from aseptically collected quarter milk (indicator for IMI) and teat apex (indicator for teat apex colonization, TAC) in dairy herds with automatic milking systems (AMS). The primary objective of this cross-sectional field study was to estimate the diagnostic Se and Sp of the commercially available Mastit4 qPCR assay and BC for diagnosis of IMI and TAC with CNS at different cut-offs for cycle threshold $(\mathrm{Ct})$ values within a Bayesian framework. A secondary objective was to evaluate two cut-offs of BC based on colony forming units (CFU) for diagnosis of IMI and TAC with CNS.

This article is protected by copyright. All rights reserved. 


\section{Materials and Methods}

\section{Study population}

During the period from February to May 2017, eight dairy herds with Danish Holstein cows were selected for participating in a project to investigate the epidemiology and diagnostics of mastitis pathogens in Danish dairy herds (Svennesen et al. 2019). To be eligible for inclusion in the present study, herds had to have AMS with $\geq 3$ milking robots and BTM qPCR Ctvalue $\leq 32$ for Streptococcus agalactiae. Between 30 and 40 lactating dairy cows were selected randomly from each herd. These cows were randomly selected among those with a SCC > 200,000 cells/mL at the preceding milk recording, and with no clinical mastitis or antimicrobial treatment four weeks prior to sample collection. From every second sampled cow (odd laboratory running numbers), teat skin swab and aseptic milk samples were taken from right hind quarter for laboratory investigation (Mahmmod et al. 2018a).

\section{Quarter samples collection}

Each herd was visited once to collect teat swab samples and aseptically collected quarter foremilk samples for BC and qPCR. The farmers were asked to separate the selected cows. Cows were fixed in head lockers during sampling. After cleaning the teats with dry paper towel, the teat swab samples were collected followed by the quarter foremilk samples. Teat swab samples were collected according to the modified wet-dry method (Paduch et al. 2013). Briefly, the first swab (Dakla Pack $^{\circledR}$ ) was moistened with 1/4 Ringer's solution (Merck, Darmstadt, Germany) and rotated $360^{\circ}$ around the teat about $1 \mathrm{~cm}$ from the teat canal orifice. The same procedure was carried out with the dry swab. Immediately after sampling, the tips of both swabs were transferred into a tube with $2 \mathrm{~mL}$ of sterile Ringer's solution.

Quarter milk samples were collected directly after harvesting the teat swab samples according to National Mastitis Council (NMC 1999) guidelines. Briefly, the teat end was thoroughly 
disinfected with cotton swabs drenched with ethanol (70\%). Individual quarter foremilk samples were then aseptically collected in sterile screw cap plastic tubes. Before sampling procedures, latex gloves were worn and changed after each cow. Tubes containing the teat skin swabs and milk samples were stored at $\max 5^{\circ} \mathrm{C}$ until laboratory analysis the following day.

\section{Diagnostic procedures}

\section{Phenotypic identification}

Bacterial culture of milk samples was conducted in accordance with National Mastitis Council recommendations (NMC 1999). After vortexing, $0.01 \mathrm{~mL}$ of the milk sample from each quarter was streaked out with disposable, calibrated bacterial loops on a quarter of a calf blood agar plate. Simultaneously, another $0.01 \mathrm{~mL}$ of the same sample was streaked out on chromogenic agar plates selective for staphylococci (SaSelect ${ }^{\mathrm{TM}}$, Bio-Rad, Marnes-laCoquette, France). Bacterial culture of teat swab samples was performed according to the procedures of Paduch et al. (2013). Briefly, the teat swab sample was vortexed before removing the swab tips from the tubes. A total of $0.1 \mathrm{~mL}$ of a swab solution was inoculated onto the agar plates and was evenly spread with a sterile Drigalski spatula onto the agar surface of calf blood agar plates and SaSelect ${ }^{\mathrm{TM}}$ media for each quarter.

All the inoculated plates were labelled with the laboratory running number and quarter and were then incubated aerobically at $37{ }^{\circ} \mathrm{C}$ for $48 \mathrm{~h}$. All plates were examined for growth of CNS colonies after $24 \mathrm{~h}$ and $48 \mathrm{~h}$. CNS species were identified on blood agar based on the phenotypic characteristics of their colonies including morphology (round, glossy) according to the National Mastitis Council recommendations (NMC 2004) and were confirmed based on their color on the selective media according to the manufacturer's guidelines. The counts (CFU) of CNS species identified on the selective medium "SaSelect"TM" were recorded at the 
quarter level for both milk and teat swab samples. Because the inoculum size was standardized, we considered these counts to be approximate counts for choosing the BC cutoffs (Mahmmod et al. 2015). We only regarded quarter milk samples and teat skin swabs having cut-off $\geq 5$ CFU of CNS on the selective agar plate (Thorberg et al. 2009). Maximum three isolates with different colony colors on the selective agar per sample were regarded for further identification at species level using Matrix-assisted laser desorption/ionization time of flight mass spectrometry (MALDI-TOF) assay (Mahmmod et al. 2018b). The bacteria were prepared for mass spectrometry analysis according to a standard extraction protocol using formic acid (Bizzini et al. 2010), as recommended by the manufacturer.

\section{Genotypic identification (qPCR assay)}

Two qPCR swabs (DNA Diagnostic FLOQ Swabs) were immersed in the corresponding milk and teat skin sample immediately after plating. The swabs were shipped to the laboratory of DNA Diagnostic A/S on the same day that $\mathrm{BC}$ was performed, for analysis 1 or 2 days later. A commercial real-time qPCR assay (M4BD, DNA Diagnostic A/S, Risskov, Denmark) was used for qPCR analysis to detect bacterial DNA directly from the milk and teat swab samples. According to the manufacturer, the qPCR assay was developed to target CNS species with a detection limit of $10 \mathrm{CFU} / \mathrm{mL}$ at cut-off $<40,10.000 \mathrm{CFU} / \mathrm{mL}$ at cut-off $<27$, and 1.000 .000 CFU/mL at cut-off $<19.5$ (Katholm, personal communication). One of the FLOQ Swabs were added directly to the deep well plate and stayed in the deep well for the first 10 min heating step before being removed. This corresponds to around $250 \mu \mathrm{l}$ sample volume added (Timonen et al. 2017). Ct-values were reported for all samples. The Ct-value represents the number of qPCR cycles required to reach the set threshold fluorescence signal level. The thermal cycling protocol for the qPCR assay involved 40 cycles for the reaction where the higher the number of bacteria present in the milk sample, the lower the Ct-value obtained 
with the assay. The assay included negative DNA extraction controls, internal amplification standard (positive qPCR controls), and non-template control. The laboratory personnel were blinded concerning cow identity and result of the corresponding BC.

\section{Test categorization}

To evaluate the diagnostic performance of $\mathrm{BC}$, we used two $\mathrm{BC}$ cut-offs $(\geq 5$ and $\geq 10$ colonies per quarter) for defining the positivity for CNS IMI and TAC. A quarter was defined as positive in milk (= IMI), if at least 5 colonies or 10 colonies of CNS were identified on the selective medium, corresponding to $500 \mathrm{CFU} / \mathrm{ml}$ or $1000 \mathrm{CFU} / \mathrm{ml}$, respectively. Likewise, a quarter was defined as positive on teat apex $(=$ TAC) if at least 5 colonies of CNS were identified, corresponding to $50 \mathrm{CFU} / \mathrm{mL}$ of the teat swab sample solution. To evaluate the diagnostic performance of qPCR, the LCA analysis was run separately for each of the qPCR cut-off values under investigation (i.e. $<40, \leq 37, \leq 34, \leq 32$ and $\leq 29$ ) against the two BC cutoffs for diagnosis of IMI and TAC.

\section{Statistical analysis}

Out of 150 eligible cows, one cow was excluded for the reason of having a dry right hind quarter. A total of 149 cows with complete observations for both qPCR and BC tests from milk and teat skin samples from right hind quarters were subjected to the LCA. We followed the guidelines for reporting of diagnostic accuracy in studies that use Bayesian LCA (Kostoulas et al. 2017). We used the results of qPCR assay and BC to implement in Bayesian LCA model to estimate the Se and Sp of each test for diagnosing IMI and TAC of CNS in dairy cattle. Essentially, Bayesian LCA models (Branscum et al. 2005) are based on the paradigm described by Hui and Walter (1980), which includes three key assumptions; 1) the target population should consist of two or more subpopulations with differing prevalences, 2) 
there should be a constant Se and Sp of the index tests across the subpopulations, and 3) the tests under evaluation should be conditionally independent given the disease status. We divided our study population into two subpopulations of herds with different densities according to geography/location, because we assumed that geography would not influence Se and Sp. Population 1 refers to herds $(\mathrm{H})$ located in Northern Denmark including H1, H2, H6, H7 and H8, while population 2 refers to herds located in Southern Denmark including H3, H4, and H5. The Hui-Walter 2-test 2-populations model was used to simultaneous estimate Se and Sp of qPCR and BC, as well as the prevalence of the investigated disease in each of the two subpopulations.

The Bayesian model was implemented in OpenBUGS software, version 3.2.3 rev 1012 (Thomas et al. 2006) to estimate the test parameters and population prevalence. This software uses a Markov Chain Monte Carlo (MCMC) sampling algorithm to obtain a Monte Carlo sample from the posterior distribution of all model parameters. The first 10.000 samples were discarded as burn-in to allow convergence. The following 20,000 iterations of the model were used for posterior inference. Convergence of the MCMC chain was assessed by visual inspection of the time-series plots of selected variables as well as by inspecting GelmanRubin diagnostic plots and autocorrelation plots using three sample chains with different initial values (Toft et al. 2007). There is no published evidence of the diagnostic properties for the tests under comparison, when applied to identify, the target condition IMI and TAC with CNS in dairy cows from AMS herds. Thus, we have chosen to use uninformative priors in the shape of uniform distributions on the interval between zero and one, using the Beta $(1,1)$ distribution to fit the model. The posterior distribution of the test properties (Se and $\mathrm{Sp}$ for $\mathrm{qPCR}$ and $\mathrm{BC}$ ) and the prevalence in the two subpopulations were reported as the median 
and corresponding 95\% posterior credibility interval (PCI, the Bayesian analog of a confidence interval).

\section{Results}

No marked difference was detected in the distribution of CNS at qPCR cut-offs $\leq 40$ and $\leq 37$ therefore, we presented the distribution and results at qPCR cut-offs $\leq 37, \leq 34, \leq 32$ and $\leq 29$. Results of cross-tabulated dichotomous outcome of qPCR and BC for detection of CNS at the different cut-offs are displayed in Table 1 (IMI) and Table 2 (TAC). The estimates of posterior median and 95\% PCI of true prevalence and Se and Sp of qPCR and BC for detection of CNS at the different cut-offs for two tests are displayed in Table 3 and 4.

As for the target condition "IMI with CNS", qPCR $\mathrm{Se}_{\text {was }}$ always higher than $\mathrm{BC}_{\mathrm{Se}}$, however; $\mathrm{BC}_{\mathrm{Sp}}$ was higher than $\mathrm{qPCR}_{\mathrm{Sp}}$ at all tested cut-offs (Table 3). BC estimates were changed by changing the $\mathrm{BC}$ cut-off. Estimates of $\mathrm{BC}_{\mathrm{Se}}$ and $\mathrm{BC}_{\mathrm{Sp}}$ showed no substantial variations across the high qPCR cut-offs, whereas at cut-off $\leq 29$ an obvious increase in $\mathrm{BC}_{\mathrm{Se}}$ was prominent, Table $3 . \mathrm{BC}_{\mathrm{Sp}}$ was decreasing by decreasing $\mathrm{qPCR}$ cut-offs, whereas $\mathrm{qPCR}_{\mathrm{Sp}}$ was increasing. Estimates of $\mathrm{BC}_{\mathrm{Se}}$ and $\mathrm{BC}_{\mathrm{Sp}}$ showed no substantial difference between the tested $\mathrm{BC}$ cut-offs. In contrast to IMI condition, estimates of BC and qPCR in diagnosing TAC with CNS were different and characterized by very wide PCIs. $\mathrm{BC}_{\mathrm{Se}}$ was higher than $\mathrm{qPCR}_{\mathrm{Se}}$ at all tested cutoffs, however; $\mathrm{qPCR}_{\mathrm{Sp}}$ was higher than $\mathrm{BC}_{\mathrm{Sp}}$ (Table 4). At higher qPCR cut-offs $(\leq 37)$, the difference between $\mathrm{qPCR}_{\mathrm{Se}}$ and $\mathrm{BC}_{\mathrm{Se}}$ was lower than the difference between their estimates at low qPCR cut-offs $(\leq 29)$, (Table 4 ). For example, at $\mathrm{BC}$ cut-off $\geq 5$, the $\mathrm{BC}_{\mathrm{Se}}$ estimate was $85 \%$ and higher than the estimate at cut-off $\geq 10(78 \%)$, whereas for $\mathrm{BC}_{\mathrm{Sp}}$, it was the other way around. BC and qPCR estimates were affected with changing cut-offs of BC and qPCR, indicating that IMI and TAC definition is associated with the chosen cut-off. The range of 95\% PCI of the estimates of qPCR and BC for diagnosis of TAC was obviously wider than 
those ranges for estimates of $\mathrm{qPCR}$ and $\mathrm{BC}$ for diagnosis of IMI. Moreover, the range of $95 \%$ PCI of BC estimates was wider than the 95\% PCI range of qPCR estimates for diagnosis of TAC.

\section{Discussion}

\section{Estimates of qPCR and BC for IMI}

Our findings showed that both tests are equally highly specific for detection of CNS from milk, whereas qPCR has a higher Se than BC at all the tested cut-offs for qPCR and BC. This is consistent with previous studies, which found that PCR shows a higher Se than BC for detecting bacteria in milk samples (Taponen et al. 2009; Shome et al. 2011; Keane et al. 2013).

The Se and Sp estimates of qPCR (94\% and 77\%) are comparable with estimates of Nyman et al. (2016), whereas our estimates of BC were higher than their estimates. That variation could be argued by the difference in the study design, inclusion criteria and sample size of study population, definition of IMI with CNS in milk, and sample type for BC and qPCR (composite Vs quarter). In their research, Nyman et al. (2016) used cut-off $\leq 37$ for qPCR and $\geq 3 \mathrm{CFU} / \mathrm{mL}$ for $\mathrm{BC}$ to define IMI with CNS. Furthermore, a different PCR test, the PathoProof test kit (Finnzymes Oy, ThermoFischer, Finland) was used, which may have a different DNA purification method and/or identification system for staphylococci species compared to the CNS in the Mastit4 qPCR test. Hiitiö et al. (2015) concluded that when using PCR as the only microbiological method for mastitis diagnostics in normally aseptically collected quarter samples, low amounts of minor pathogens such as CNS should be ignored. In our study, on aseptically taken quarter milk samples, we found that Se estimate of qPCR was higher than that of BC. This finding may be applicable to low and high SCC cows, but keeping in mind our selection criteria (cows with high SCC $>200.000$ cell $/ \mathrm{ml}$ ), the 
findings could be more relevant for those cows that meet such criterion. Using a conjoint analysis approach, Andersen et al. (2010) reported that $20 \%$ of the times when CNS were isolated on the test day, the quarter was considered IMI-negative according to the consensus standard rules (i.e., a- the organism of interest was isolated on the test day with 10 colonies or more, and b- the organism of interest was isolated at least twice out of 3 consecutive weekly tests). This finding could have different reasons such as a) culture with staphylococci in quarters with subclinical IMI, often have less than 10 colonies, b) CNS clear spontaneously from the quarter (Ruegg 2009; Taponen and Pyörälä 2009), and c) CNS are not growing/ detected at every sampling time point. The finding of Andersen et al. (2010) and subsequent explanations could explain the difference between our study findings (quarter level, crosssectional) and those of Hiitiö et al. (2015) at quarter level and Nyman et al. (2016) at cow level. Dohoo et al. (2011) evaluated several definitions for classifying a quarter as having, or not having an IMI with CNS by comparing the results from a single bacterial culture to a gold standard diagnosis based on a set of three weekly taken milk samples. Our Sp estimates of BC at the two BC cut-offs ( $\geq 5$ and $\geq 10$ ) were $92 \%$, and $94 \%$, while those estimates reported by Dohoo et al. (2011) at cut-off definitions $\geq 2$, and $\geq 10$ were all above $99 \%$ for those quarters with minimum SCC threshold 200,000 cells $/ \mathrm{mL}$, which are the same selection criteria as in the current study. Meanwhile, our Se estimates of BC, regardless the BC cutoffs, were higher than those estimates obtained by Dohoo et al. (2011) based on the gold standard approach. This difference could be explained by the use of an imperfect reference test that result in misclassification bias (Toft et al. 2005). Using traditional diagnostic test evaluation, Reyher and Dohoo (2011) reported Se (60\%) and Sp (83\%) estimates for CNS IMI based on composite milk samples at cut-off $\geq 1 \mathrm{CFU}$ for IMI. Our BC estimates at the tested cut-offs showed higher Se (above 63\%) but also higher Sp (above 92\%).

This article is protected by copyright. All rights reserved. 
Several factors could explain the variation between our estimates of Se and Sp for BC and qPCR tests for IMI and TAC. For example, time of sampling for BC and qPCR (test day versus early lactation sampling), sampling type (quarter versus composite sampling), and study design could have a substantial impact on the test performance. Additionally, udder health management practices and milking system type (conventional versus automatic) as well as the choice of qPCR Ct-value cut-off, type of PCR, and IMI definitions on BC may have an effect. Previous research demonstrated that management of udder health under conventional milking systems differs from AMS (Dohmen et al. 2010; Sørensen et al. 2016). Cows in AMS can be milked up to 5 times daily leading to frequent exposure of the teat skin to the teat milking preparations and disinfectants, which may affect the teat apex microbiota. Furthermore, application of teat spray in the AMS is imperfect compared to routine teat dipping in conventional system. Hovinen and Pyörälä (2011) showed that CNS was reported the most common cause of IMI in cows milked in AMS. In this study, only cows with elevated SCC were included, which could have increased the probability of CNS detection by qPCR and BC and thus, increased Se estimates compared to Dohoo et al. (2011). Svennesen et al. (2018) stated that sampling cows only with SCC > 200,000 cells/mL may have increased the frequency of IMI and the test performance due to an increased chance of a high concentration of bacteria in IMI quarters with an active infection. In line with this conclusion, Condas et al. (2017a) reported that $S$. chromogenes, S. simulans, S. xylosus, S. haemolyticus, S. epidermidis, S. agnetis, S. arlettae, S. capitis, S. gallinarum, S. sciuri, and S. warneri were more prevalent in high than in low SCC udder quarters.

IMI with CNS are less severe and/ or mild in comparison to contagious pathogens (e.g., $S$. aureus and Streptococcus agalactiae). Furthermore, most of research studies consider the presence of a single CFU of contagious mastitis pathogens or major pathogens as an 
acceptable definition of IMI, whereas the presence of a single or double CFU of CNS may not be considered as an indicator of IMI with CNS, which requires urgent interventions. Therefore, higher cut-offs are reported to define IMI with CNS, such as $\geq 5 \mathrm{CFU} / \mathrm{mL}$ for CNS (Thorberg et al. 2009; Bexiga et al. 2011b) and $\geq 10$ CFU/mL (Tomazi et al. 2015; Dolder et al. 2017; Condas et al. 2017b). Additionally, TAC with CNS species increases the risk of false positive samples (Friman et al. 2017) and therefore, finding of few CFU in milk can be labelled as "contamination" rather than true IMI and thus, be disregarded. Consequently, higher CFU cut-offs to increase $\mathrm{Sp}$ at the cost of lower Se may be preferable in udder health management.

\section{Estimates of qPCR and BC for TAC}

Our findings showed that both tests succeeded in detecting CNS from the teat apex. BC showed a higher Se than qPCR, but lower Sp across the tested cut-offs in diagnosis of TAC with CNS. The detectable high Se of BC and low Se of qPCR in detection of CNS from teat skin can be argued by many factors. For instance, a) the inoculum volume submitted for the diagnostic test was $0.1 \mathrm{~mL}$ of a swab solution for $\mathrm{BC}$, and around $0.25 \mathrm{~mL}$ for the $\mathrm{qPCR}$, but in the extraction and lysis process the test volume is reduced 12 times so this is compared to $0.02 \mathrm{~mL}$, and b) the sampling technique, which seems to influence largely the amount of extracted DNA. To test the latter assumption, a set of 73 CNS isolates from teat skin were preserved in glycerol at $-80^{\circ} \mathrm{C}$ (data not shown) and identified to species level using MALDI-TOF assay. These isolates were subjected to the same qPCR assay at DNA Diagnostic's laboratory for validation. The results showed that the qPCR assay identifies successfully all the submitted CNS isolates with high accuracy indicating that the reported low Se is probably due to effect of sampling technique. We reported the full description of 15 CNS species isolated from the teat skin samples in Mahmmod et al. (2018b) including $S$. 
arlettae, S. capitis, S. chromogenes, S. cohnii, S. epidermidis, S. equorum, S. haemolyticus, S. hominis, S. piscifermentans, S. saprophyticus, S. sciuri, S. succinus, S. vitulinus, S. warneri, and S. xylosus. Using the same study design, Skjølstrup et al. (2018) reported that Se of qPCR on teat skin was $30 \%$ for the identification of $S$. aureus compared with $91 \%$ for a sampling method where special qPCR swabs "FLOQ swabs" were directly applied on the teat skin for swabbing. FLOQ swabs differ from the ordinary cotton swabs by consisting of short nylon fibers, which do not absorb material but facilitates uptake of fluid while keeping material close to the surface to allow rapid elution. This indicates that sampling technique has an important impact on qPCR test results and that collecting the teat swab samples for qPCR using FLOQ swabs will considerably improve the Se of qPCR. According to the manufacturer, the detection of bacteria isolates directly in water samples is inefficient with the Mastit4 qPCR. We therefore, think that testing of the fluid from the teat swab samples, despite being collected with the FLOQ swab, is still a water sample, which may contain too little cells or other debris that make the bacterial detection from the pellet in the two centrifugation steps of the Mastit4 test inefficient for the water samples. This argument gives a plausible explanation to the obtained low Se of qPCR for TAC with CNS. Previous studies concluded that the sampling technique based on an experimental set-up using needle puncture (Hiitiö et al. 2016) or through cannula (Friman et al. 2017) has an obvious effect on the results of microbiological methods and PCR-based techniques for bovine mastitis diagnosis. A huge variety of bacterial communities are sharing the teat skin habitat and form the normal microbiota system (Falentin et al. 2016). Therefore, identification of CNS species using phenotypic methods from the teat skin is a challenge.

In our recent study, Svennesen et al. (2018) reported a different pattern of the Se and Sp estimates for qPCR and BC of Streptococcus agalactiae (qPCR: 0.97 and 0.96 - BC: 0.33 and 1.00) and S. aureus (qPCR: 0.94 and $0.98-$ BC: 0.44 and 0.74) in teat skin samples, 
respectively. The remarkable variation between our estimates in this study and our previous study (Svennesen et al. 2018) could be argued by difference in the target pathogen (contagious versus environmental), and cut-off detection limit for qPCR (Ct value $\leq 37$ versus multiple $\mathrm{Ct}$ value cut-offs) and $\mathrm{BC}$ (single colony versus $\geq 5$ colonies).

The Se and Sp of the selective agar (SaSelect ${ }^{\mathrm{TM}}$ ) for staphylococci species was $98 \%$ and 99.9\% according to the manufacturer manual but could perform differently for teat skin samples than milk. According to the manufacturer's instructions, the majority of microorganisms, other than staphylococci, are inhibited. However, Corynebacterium, bacillus, certain gram-negative rods, and yeasts can sometimes grow on SaSelect ${ }^{\mathrm{TM}}$ agar. In this regard, MALDI-TOF identified 6\% (25/396) of the submitted teat skin isolates, which were originally identified as CNS on culture as Bacillus pumilis, Aerococcus viridans, or Corynebacterium stationis (Mahmmod et al. 2018b). We, therefore, think that some of the colonies identified as CNS on BC could be other bacterial species, which were misidentified as CNS.

Typically, molecular methods such as qPCR can target the CNS species for which they have been designed based on their relevance for udder health, whereas in $\mathrm{BC}$ most species able to grow- whether it is pathogenic or commensal - can potentially be identified (Koskinen et al. 2010). Although Se of BC was higher than Se of qPCR, it was noted that the range of $95 \%$ PCI of the estimates of BC was wider than 95\% PCI range of qPCR estimates for diagnosis of TAC, which makes our reliance on $\mathrm{qPCR}$ is preferable. Moreover, $\mathrm{BC}$ at its best performance, is still a phenotypic identification method that may have some shortcomings such as need for experienced laboratory personnel, and subjectivity despite the standardized procedures (Sears and McCarthy 2003). Additionally, other confirmatory tests (e.g., biochemical identification) are needed for definite identification of colonies are necessary. 


\section{Test properties and cut-offs}

The Se and Sp estimates of BC within the frame of each BC cut-off were not affected or changed much by changing the qPCR cut-offs confirming that $\mathrm{BC}$ is measuring the same target (i.e., viable cells of CNS), unlike the target of qPCR. The same pattern was also noted for qPCR estimates where Se and Sp estimates of qPCR within the frame of each BC cut-off were not proportionally changed by changing the BC cut-offs confirming that qPCR is measuring the same target (i.e., DNA of CNS), apart from the detection target of BC. This comes in agreement with the findings of previous studies (Mahmmod et al. 2013a; Soltau et al. 2017). One of the main different aspects between the $\mathrm{qPCR}$ analysis and BC is that $\mathrm{qPCR}$ analysis detects DNA, whereas BC detects only viable bacteria. Thus, the detected DNA by qPCR can come from bacteria that are viable or killed by the immune system, or, in case of TAC, by teat spray applied after milking. Cressier and Bissonnette (2011) added that, unlike BC, qPCR detects bacterial DNA, which means that it is not dependent on the viability of bacteria which creates difficulty when interpreting whether a positive qPCR result is significant. However, the Mastit4 qPCR test is not detecting free DNA in the milk sample. Only DNA inside viable cells or intact dead cells that still house the DNA is centrifuged to a pellet and then later released from the cells in the lysis process.

\section{Model assumptions}

When applying LCA to estimate test performance of diagnostic tests, there are model assumptions and conditions to consider. The first implied assumption of LCA model is that the two tests (qPCR and $\mathrm{BC}$ ) are conditionally independent given disease status. This assumption is fulfilled because $\mathrm{qPCR}$ and $\mathrm{BC}$ have different biological identification mechanisms. Furthermore, no culturing was involved in the qPCR procedure. The second assumption that the test characteristics ( $\mathrm{Se}$ and $\mathrm{Sp}$ ) should be constant across the tested 
populations was fulfilled as herd geographical location would not affect test characteristics. The final assumption is that prevalence of infection/disease status should differ between populations. We assumed a priori that the apparent prevalences of CNS IMI and/or TAC differs among the eight herds due to different herd management. That assumption was verified, as posterior estimates of prevalences in our study were markedly different (Table 3 and Table 4).

In conclusion, we estimated the Se and $\mathrm{Sp}$ of both the conventional BC and the qPCR assay for diagnosis of IMI and TAC with CNS at different cut-offs for qPCR and BC using latent class analysis approach. The qPCR showed a higher Se than BC across the tested cut-offs and, hence holds better promise for routine use in diagnosis of IMI with CNS. BC showed a higher Se than qPCR but lower Sp across the tested cut-offs in diagnosis of TAC with CNS. However, it appears that BC and qPCR are partially detecting the same CNS from teat skin. Further research may be necessary to investigate the sampling technique for qPCR on teat skin. To conclude, $\mathrm{qPCR}$ and $\mathrm{BC}$ are valid diagnostics for identification of CNS in milk. However, the overall performance of qPCR was better than BC suggesting its usefulness for diagnosis of IMI with CNS. For detection of CNS in teat skin, BC showed a higher performance than qPCR however, both techniques require further investigation to reduce the uncertainty of the true status of the quarter and teat skin.

\section{Acknowledgments}

The study was part of the research project 'STOPMAST' financed by Milk Levy Foundation. DNA diagnostic A/S supported the PCR analysis. We gratefully acknowledge the efforts of

Nanna Skjølstrup (University of Copenhagen), Louise Mathiasen (University of Copenhagen), and Bettina Nonnemann (Technical University of Denmark) for helping with 
laboratory procedures. Thanks to the Danish farmers for making their cows available for our study. Thanks to the laboratory technicians for their technical and logistic support.

\section{Declaration of Interests}

Our co-author Jørgen Katholm is affiliated with DNA Diagnostic A/S, which provided us with the PCR swabs and ran the qPCR analyses in their laboratory. We confirm that the laboratory personnel was blinded to the sample identification and results of bacterial culture, and that the company had no impact on the data handling or statistical analysis. Therefore, DNA Diagnostic A/S could not bias the contents of this paper.

\section{References}

Andersen, S., Dohoo, I.R., Olde Riekerink, R. and Stryhn, H. (2010) Mastitis Research Workers' Conference. Diagnosing intramammary infections: evaluating expert opinions on the definition of intramammary infection using conjoint analysis. J Dairy Sci 93, 29662975.

Bexiga, R., Ellis, K.A., Vilela, C.L. and Mellor, D.J. (2011a). Deterministic model to evaluate the impact of lactational treatment of subclinical mastitis due to coagulasenegative staphylococci. J Dairy Res 78, 318-25.

Bexiga, R., Koskinen, M.T., Holopainen, J., Carneiro, C., Pereira, H., Ellis, K.A. and Vilela, C.L. (2011b) Diagnosis of intramammary infection in samples yielding negative results or minor pathogens in conventional bacterial culturing. J Dairy Res 78, 49-55.

Bizzini, A., Durussel, C., Bille, J., Greub, G. and Prodhom, G. (2010) Performance of matrixassisted laser desorption/ ionization-time of flight mass spectrometry for identification of bacterial strains routinely isolated in a clinical microbiology laboratory. J Clin Microbiol 48, $1549-1554$. 
Branscum, A.J., Gardner, I.A. and Johnson, W.O. (2005) Estimation of diagnostic-test sensitivity and specificity through Bayesian modeling. Prev. Vet. Med. 68, 145-163.

Cederlof, S.E., Toft, N., Aalbaek, B. and Klaas, I.C. (2012) Latent class analysis of the diagnostic characteristics of PCR and conventional bacteriological culture in diagnosing intramammary infections caused by Staphylococcus aureus in dairy cows at dry off. Acta Vet Scand 54, 65.

Condas, L.A.Z., De Buck, J., Nobrega, D.B., Carson, D.A., Naushad, S., De Vliegher, S., Zadoks, R.N., Middleton, J.R., Dufour, S., Kastelic, J.P. and Barkema, H.W. (2017b) Prevalence of non-aureus staphylococci species causing intramammary infections in Canadian dairy herds. J Dairy Sci 100, 5592-5612.

Condas, L.A.Z., De Buck, J., Nobrega, D.B., Carson, D.A., Roy, J.P., Keefe, G.P., DeVries, T.J., Middleton, J.R., Dufour, S. Barkema, H.W. (2017a) Distribution of non-aureus staphylococci species in udder quarters with low and high somatic cell count, and clinical mastitis. J Dairy Sci 100, 5613-5627.

Cressier, B. and Bissonnette, N. (2011) Assessment of an extraction protocol to detect the major mastitis-causing pathogens in bovine milk. J Dairy Sci 94, 2171-2184.

De Visscher, A., Piepers, S., Haesebrouck, F. and De Vliegher, S. (2016) Intramammary infection with coagulase-negative staphylococci at parturition: Species-specific prevalence, risk factors, and effect on udder health. J Dairy Sci 99, 6457-6469.

Dohmen, W., Neijenhuis F. and Hogeveen, H. (2010) Relationship between udder health and hygiene on farms with an automatic milking system. J Dairy Sci 93, 4019-33.

Dohoo, I.R. (2014) Bias--is it a problem, and what should we do? Prev Vet Med 113, 331337.

This article is protected by copyright. All rights reserved. 
Dohoo, I.R., Smith, J., Andersen, S., Kelton, D.F. and Godden, S. (2011) Diagnosing intramammary infections: evaluation of definitions based on a single milk sample. J Dairy Sci 94, 250-261.

Dolder, C., van den Borne, B.H.P., Traversari, J., Thomann, A., Perreten, V. and Bodmer, M. (2017) Quarter- and cow-level risk factors for intramammary infection with coagulasenegative staphylococci species in Swiss dairy cows. J Dairy Sci 100, 5653-5663

Falentin, H., Rault, L., Nicolas, A., Bouchard, D.S., Lassalas, J., Lamberton, P., Aubry, J-M., Marnet, P-G., Le Loir, Y. and Even, S. (2016) Bovine teat microbiome analysis revealed reduced alpha diversity and significant changes in taxonomic profiles in quarters with a history of mastitis. Front Microbiol 7, 480.

Friman, M., Hiitiö, H., Niemi, M., Holopainen, J., Pyörälä, S. and Simojoki, H. (2017) The effect of a cannula milk sampling technique on the microbiological diagnosis of bovine mastitis. Vet $J$ 226, 57-61.

Haine, D., Dohoo, I., Scholl, D. and Dufour, S. (2018) Diagnosing intramammary infection: Controlling misclassification bias in longitudinal udder health studies. Prev Vet Med 150, $162-167$.

Hiitiö, H., Riva, R., Autio, T., Pohjanvirta, T., Holopainen, J., Pyörälä, S. and Pelkonen, S. (2015) Performance of a real-time PCR assay in routine bovine mastitis diagnostics compared with in-depth conventional culture. J Dairy Res 82, 200-208.

Hiitiö, H., Simojoki, H., Kalmus, P., Holopainen, J., Pyörälä, S. and Taponen, S. (2016) The effect of sampling technique on PCR-based bacteriological results of bovine milk samples. J Dairy Sci 99, 6532-6541.

Holmøy, I.H., Toft, N., Jørgensen, H.J., Mørk, T., Sølverød, L. and Nødtvedt, A. (2018) Latent class analysis of real time qPCR and bacteriological culturing for the diagnosis of Streptococcus agalactiae in cow composite milk samples. Prev Vet Med 154, 119-123.

This article is protected by copyright. All rights reserved. 
Hovinen, M. and Pyörälä, S. (2011) Invited review: udder health of dairy cows in automatic milking. J Dairy Sci 94, 547-62.

Hui, S.L. and Walter, S.D. (1980) Estimating the error rates of diagnostic tests. Biometrics 36, 167-171.

Katholm, J., Bennedsgaard, T.W., Koskinen, M.T. and Rattenborg, E. (2012) Quality of bulk tank milk samples from Danish dairy herds based on real-time polymerase chain reaction identification of mastitis pathogens. J Dairy Sci 95, 5702-5708.

Keane, O.M., Budd, K.E., Flynn, J. and McCoy, F. (2013) Increased detection of mastitis pathogens by real-time PCR compared to bacterial culture. Vet Rec 173, 268-273.

Koskinen, M.T., Wellenberg, G.J., Sampimon, O.C., Holopainen, J., Rothkamp, A., Salmikivi, L., van Haeringen, W.A., Lam, T.J. and Pyörälä, S. (2010) Field comparison of real-time polymerase chain reaction and bacterial culture for identification of bovine mastitis bacteria. J Dairy Sci 93, 5707-5715.

Kostoulas, P., Nielsen, S.S., Branscum, A.J., Johnson, W.O., Dendukuri, N., Dhand, N.K., Toft, N. and Gardner, I.A. (2017) STARD-BLCM: Standards for the Reporting of Diagnostic accuracy studies that use Bayesian Latent Class Models. Prev Vet Med 138, $37-47$.

Mahmmod, Y.S., Klaas, I.C. and Enevoldsen, C. (2017) DNA carryover in milk samples from routine milk recording used for PCR-based diagnosis of bovine Staphylococcus aureus mastitis. J Dairy Sci 100, 5709-5716.

Mahmmod, Y.S., Klaas, I.C., Katholm, J., Lutton, M. and Zadoks, R.N. (2015) Molecular epidemiology and strain-specific characteristics of Streptococcus agalactiae at the herd and cow level. J Dairy Sci 98, 6913-6924.

This article is protected by copyright. All rights reserved. 
Mahmmod, Y.S., Klaas, I.C., Svennesen, L., Pedersen, K. and Ingmer, H. (2018a) Communications of Staphylococcus aureus and non-aureus Staphylococcus species from bovine intramammary infections and teat apex colonization. J Dairy Sci 101, 7322-7333.

Mahmmod, Y.S., Mweu, M.M., Nielsen, S.S., Katholm, J. and Klaas, I.C. (2014) Effect of carryover and presampling procedures on the results of real-time PCR used for diagnosis of bovine intramammary infections with Streptococcus agalactiae at routine milk recordings. Prev Vet Med 113, 512-521.

Mahmmod, Y.S., Nonnemann, B., Svennesen, L., Pedersen, K. and Klaas, I.C. (2018b)

Typeability of MALDI-TOF assay for identification of non-aureus Staphylococci associated with bovine intramammary infections and teat apex colonization. J Dairy Sci 101, 9430-9438.

Mahmmod, Y.S., Toft, N., Katholm, J., Grønbæk, C. and Klaas, I.C. (2013b) Bayesian estimation of test characteristics of real-time PCR, bacteriological culture and California mastitis test for diagnosis of intramammary infections with Staphylococcus aureus in dairy cattle at routine milk recordings. Prev Vet Med 112, 309-317.

Mahmmod, Y.S., Toft, N., Katholm, J., Grønbæk, C. and Klaas, I.C. (2013a) Estimation of test characteristics of real-time PCR and bacterial culture for diagnosis of subclinical intramammary infections with Streptococcus agalactiae in Danish dairy cattle in 2012 using latent class analysis. Prev Vet Med 109, 264-70.

National Mastitis Council (2004) Microbiological Procedures for the Diagnosis of Bovine Udder Infections and Determination of Milk Quality, $4^{\text {th }}$ ed. NMC, Madison, WI.

Nobrega DB, Naushad, S., Naqvi, S.A., Condas, L.A.Z., Saini, V., Kastelic, J.P., Luby, C., De Buck, J. and Barkema, H.W. (2018) Prevalence and genetic basis of antimicrobial resistance in non-aureus staphylococci isolated from Canadian dairy herds. Front Microbiol 9, 256.

This article is protected by copyright. All rights reserved. 
Nyman, A.K., Persson Waller, K., Emanuelson, U. and Frössling, J. (2016) Sensitivity and specificity of PCR analysis and bacteriological culture of milk samples for identification of intramammary infections in dairy cows using latent class analysis. Prev Vet Med 135, 123-131.

Paduch, J. H., Mohr, E. and Kromker, V. (2013) The association between bedding material and the bacterial counts of Staphylococcus aureus, Streptococcus uberis and coliform bacteria on teat skin and in teat canals in lactating dairy cattle. J Dairy Res 80, 159-164.

Persson Waller, K. (2013) "Microbiological diagnostics of udder infections" The $29^{\text {th }}$ NKVet Symposium "New knowledge on diagnostics and control on modern dairy farms".

Piepers, S., De Meulemeester, L., de Kruif, A., Opsomer, G., Barkema, H.W. and De Vliegher, S. (2007) Prevalence and distribution of mastitis pathogens in subclinically infected dairy cows in Flanders, Belgium. J Dairy Res 74, 478-83.

Piessens, V., De Vliegher, S., Verbist, B., Braem, G., Van Nuffel, A., De Vuyst, L., Heyndrickx, M. and Van Coillie, E. (2012) Intra-species diversity and epidemiology varies among coagulase-negative Staphylococcus species causing bovine intramammary infections. Vet Microbiol 155, 62-71.

Qu, Y., Zhao, H., Nobrega, D.B., Cobo, E.R., Han, B., Zhao, Z., Li, S., Li, M., Barkema, H.W. and Gao, J. (2019) Molecular epidemiology and distribution of antimicrobial resistance genes of Staphylococcus species isolated from Chinese dairy cows with clinical mastitis. J Dairy Sci 102, 1571-1583.

Reyher, K.K. and Dohoo, I.R. (2011) Diagnosing intramammary infections: evaluation of composite milk samples to detect intramammary infections. J Dairy Sci 94, 3387-3396.

Ruegg, P.L., 2009. The quest for the perfect test: phenotypic versus genotypic identification of coagulase-negative staphylococci associated with bovine mastitis. Vet. Microbiol. 134, 15-9.

This article is protected by copyright. All rights reserved. 
Schukken, Y. H., Gonzalez, R.N., Tikofsky, L.L., Schulte, H.F., Santisteban, C.G., Welcome, F.L., Bennett, G.J., Zurakowski, M.J. and Zadoks, N. (2009) CNS mastitis: Nothing to worry about? Vet Microbiol 134, 9-14.

Sears, P.M. and McCarthy, K.K. (2003) Diagnosis of mastitis for therapy decisions. Vet Clin North Am Food Anim Pract 19, 93-108.

Shome, B.R., Das Mitra, S., Bhuvana, M., Krithiga, N., Velu, D., Shome, R., Isloor, S., Barbuddhe, S.B. and Rahman, H. (2011) Multiplex PCR assay for species identification of bovine mastitis pathogens. J Appl Microbiol 111, 1349-56.

Skjølstrup, N.K., Mathiasen, L.R., Klaas, I.C., Svennesen, L., Mahmmod, Y. and Pedersen, K. (2018) Validation of real-time PCR and bacteriological culture for identification of Streptococcus agalactiae and Staphylococcus aureus in milk and on teat skin in herds with automatic milking system. National Mastitis Council $57^{\text {th }}$ Annual Meeting, $31^{\text {st }}$ January to $2^{\text {nd }}$ February 2018, Tucson, Arizona, US.

Soltau, J.B., Einax, E., Klengel, K., Katholm, J., Failing, K., Wehrend, A. and Donat, K. (2017) Within-herd prevalence thresholds for herd-level detection of mastitis pathogens using multiplex real-time PCR in bulk tank milk samples. J Dairy Sci 100, 8287-8295.

Sørensen, L.P., Bjerring, M. and Løvendahl, P. (2016) Monitoring individual cow udder health in automated milking systems using online somatic cell counts. J Dairy Sci 99, 608620

Sørensen, L.P., Mark, T., Sørensen, M.K. and Ostergaard, S. (2010) Economic values and expected effect of selection index for pathogen-specific mastitis under Danish conditions. J Dairy Sci 93, 358-369.

Souza, F.N., Piepers, S., Della Libera, A.M.M.P., Heinemann, M.B., Cerqueira, M.M.O.P. and De Vliegher, S. (2016) Interaction between bovine-associated coagulase-negative 
staphylococci species and strains and bovine mammary epithelial cells reflects differences in ecology and epidemiological behavior. J Dairy Sci 99, 2867-2874.

Steele, N.M., Williamson, J.H., Thresher, R., Laven, R.A. and Hillerton, J.E. (2017) Evaluating a commercial PCR assay against bacterial culture for diagnosing Streptococcus uberis and Staphylococcus aureus throughout lactation. J Dairy Sci 100, 3816-3824.

Supré, K., Haesebrouck, F., Zadoks, R.N., Vaneechoutte, M., Piepers, S. and De Vliegher, S. (2011) Some coagulase-negative Staphylococcus species affect udder health more than others. J Dairy Sci 94, 2329-2340.

Svennesen, L., Mahmmod, Y.S., Skjølstrup, N.K., Mathiasen, L.R., Katholm, J., Pedersen, K., Klaas, I.C. and Nielsen, S.S. (2018) Accuracy of qPCR and bacterial culture for the diagnosis of bovine intramammary infections Taponen colonisation with Streptococcus agalactiae and Staphylococcus aureus using Bayesian analysis. Prev Vet Med 161, 69-74.

Svennesen, L., Nielsen, S.S., Mahmmod, Y.S., Krömker, V., Pedersen, K. and Klaas, I.C. (2019) Association between teat skin colonization and intramammary infection with Staphylococcus aureus and Streptococcus agalactiae in herds with automatic milking systems. J Dairy Sci 102, 629-639.

Taponen, S. and Pyörälä, S. (2009) Coagulase-negative staphylococci as cause of bovine mastitis- not so different from Staphylococcus aureus? Vet Microbiol 134, 29-36.

Taponen, S., Salmikivi, L., Simojoki, H., Koskinen, M.T. and Pyörälä, S. (2009) Real-time polymerase chain reaction-based identification of bacteria in milk samples from bovine clinical mastitis with no growth in conventional culturing. J Dairy Sci 92, 2610-2617.

Thomas, A., O’Hara, B., Ligges, U. and Sturtz, S. (2006) Making BUGS open. R News 6, $12-$ 17.

This article is protected by copyright. All rights reserved. 
Thorberg, B.M., Danielsson-Tham, M.L., Emanuelson, U. and Persson Waller, K. (2009) Bovine subclinical mastitis caused by different types of coagulase-negative staphylococci. J Dairy Sci 92, 4962-4970.

Timonen, A.A.E., Katholm, J., Petersen, A., Mõtus, K. and Kalmus, P. (2017) Within-herd prevalence of intramammary infection caused by Mycoplasma bovis and associations between cow udder health, milk yield, and composition. J Dairy Sci 100, 6554-6561.

Toft, N., Innocent, G.T., Gettinby, G. and Reid, S.W.J. (2007) Assessing the convergence of Markov Chain Monte Carlo methods: an example from evaluation of diagnostic tests in absence of a gold standard. Prev Vet Med 79, 244-256.

Toft, N., Jørgensen, E. and Højsgaard, S. (2005) Diagnosing diagnostic tests: evaluating the assumptions underlying the estimation of sensitivity and specificity in the absence of a gold standard. Prev Vet Med 68, 19-33.

Tomazi, T., Gonçalves, J.L., Barreiro, J.R., Arcari, M.A. and dos Santos, M.V. (2015) Bovine subclinical intramammary infection caused by coagulase-negative staphylococci increases somatic cell count but has no effect on milk yield or composition. J Dairy Sci 98, 30713078 .

Vanderhaeghen, W., Piepers, S., Leroy, F., Van Coillie, E., Haesebrouck, F. and De Vliegher, S. (2014) Invited review: Effect, persistence, and virulence of coagulase-negative Staphylococcus species associated with ruminant udder health. J Dairy Sci 97, 5275-5293. Wilson, D.J., González, R.N., Hertl, J., Schulte, H.F., Bennett, G.J., Schukken, Y.H. and Gröhn, Y.T. (2004) Effect of clinical mastitis on the lactation curve: a mixed model estimation using daily milk weights. J Dairy Sci 87, 2073-84.

This article is protected by copyright. All rights reserved. 
Table 1. Cross-tabulated results for combinations of qPCR at different qPCR Ct-values cutoffs, and BC at two CFU cut-offs for diagnosis of IMI with CNS in the right hind quarter from 149 cows in 8 Danish dairy herds with AMS stratified based on the location of herd to two subpopulations (Pop 1= north "5 herds" and Pop 2= south " 3 herds")

\begin{tabular}{|c|c|c|c|c|c|c|c|}
\hline \multirow[t]{2}{*}{ BC cutoff } & \multirow[t]{2}{*}{$\begin{array}{l}\text { qPCR } \\
\text { cutoff }\end{array}$} & \multirow[t]{2}{*}{ Population } & \multicolumn{4}{|c|}{$\begin{array}{c}\text { Test combinations } \\
\text { (T1; qPCR and T2; BC) for IMI }\end{array}$} & \multirow[t]{2}{*}{$\begin{array}{c}\text { Total } \\
(\%)\end{array}$} \\
\hline & & & $\mathrm{T} 1+/ \mathrm{T} 2+$ & $\mathrm{T} 1+/ \mathrm{T} 2-$ & T1-/T2+ & T1-/T2- & \\
\hline \multirow{10}{*}{$\begin{array}{c}\geq 5 \\
\text { colonies } \\
(=500 \\
\text { CFU } / \mathrm{ml})\end{array}$} & \multirow[t]{2}{*}{$\leq 37$} & Pop 1 (north) & 31 & 22 & 4 & 34 & 91 \\
\hline & & Pop 2 (south) & 29 & 18 & 2 & 9 & 58 \\
\hline & \multirow[t]{2}{*}{$\leq 34$} & Pop 1 (north) & 31 & 22 & 4 & 34 & 91 \\
\hline & & Pop 2 (south) & 29 & 18 & 2 & 9 & 58 \\
\hline & \multirow[t]{2}{*}{$\leq 32$} & Pop 1 (north) & 29 & 18 & 6 & 38 & 91 \\
\hline & & Pop 2 (south) & 27 & 17 & 4 & 10 & 58 \\
\hline & \multirow[t]{2}{*}{$\leq 29$} & Pop 1 (north) & 23 & 9 & 12 & 47 & 91 \\
\hline & & Pop 2 (south) & 25 & 9 & 6 & 18 & 58 \\
\hline & \multirow[t]{2}{*}{$\leq 26$} & Pop 1 (north) & 12 & 5 & 23 & 51 & 91 \\
\hline & & Pop 2 (south) & 21 & 5 & 10 & 22 & 58 \\
\hline \multirow{3}{*}{$\begin{array}{l}\geq 10 \\
\text { colonies }\end{array}$} & \multirow[t]{2}{*}{$\leq 37$} & Pop 1 (north) & 25 & 28 & 3 & 35 & 91 \\
\hline & & Pop 2 (south) & 27 & 20 & 1 & 10 & 58 \\
\hline & \multirow[t]{2}{*}{$\leq 34$} & Pop 1 (north) & 25 & 28 & 3 & 35 & 91 \\
\hline \multirow{7}{*}{$\mathrm{CFU} / \mathrm{ml}$ ) } & & Pop 2 (south) & 27 & 20 & 1 & 10 & 58 \\
\hline & \multirow[t]{2}{*}{$\leq 32$} & Pop 1 (north) & 24 & 23 & 4 & 40 & 91 \\
\hline & & Pop 2 (south) & 25 & 19 & 3 & 11 & 58 \\
\hline & \multirow[t]{2}{*}{$\leq 29$} & Pop 1 (north) & 19 & 13 & 9 & 50 & 91 \\
\hline & & Pop 2 (south) & 24 & 10 & 4 & 20 & 58 \\
\hline & \multirow[t]{2}{*}{$\leq 26$} & Pop 1 (north) & 11 & 6 & 17 & 57 & 91 \\
\hline & & Pop 2 (south) & 20 & 6 & 8 & 24 & 58 \\
\hline
\end{tabular}

This article is protected by copyright. All rights reserved. 
Table 2. Cross-tabulated results for combinations of qPCR at different qPCR Ct-values cutoffs, and BC at two cut-offs for diagnosis of CNS in teat skin colonization (TAC) in the right hind quarter from 149 cows in 8 Danish dairy herds with AMS stratified based on the location of herd to two subpopulations (Pop 1= north "5 herds" and Pop $2=$ south " 3 herds")

\begin{tabular}{|c|c|c|c|c|c|c|c|}
\hline \multirow[t]{2}{*}{$\begin{array}{c}\text { BC } \\
\text { cutoff }\end{array}$} & \multirow[t]{2}{*}{$\begin{array}{l}\text { qPCR } \\
\text { cutoff }\end{array}$} & \multirow[t]{2}{*}{ Population } & \multicolumn{4}{|c|}{$\begin{array}{c}\text { Test combinations } \\
(\mathrm{T} 1 ; \mathrm{qPCR} \text { and } \mathrm{T} 2 ; \mathrm{BC}) \text { for TAC }\end{array}$} & \multirow[t]{2}{*}{$\begin{array}{c}\text { Total } \\
(\%)\end{array}$} \\
\hline & & & $\mathrm{T} 1+/ \mathrm{T} 2+$ & $\mathrm{T} 1+/ \mathrm{T} 2-$ & T1-/T2+ & T1-/T2- & \\
\hline \multirow{10}{*}{$\begin{array}{c}\geq 5 \\
\text { colonies } \\
(=50 \\
\text { CFU/ml })\end{array}$} & \multirow[t]{2}{*}{$\leq 37$} & Pop 1 (north) & 38 & 9 & 35 & 9 & 91 \\
\hline & & Pop 2 (south) & 25 & 0 & 29 & 4 & 58 \\
\hline & \multirow{2}{*}{$\leq 34$} & Pop 1 (north) & 37 & 8 & 36 & 10 & 91 \\
\hline & & Pop 2 (south) & 25 & 0 & 29 & 4 & 58 \\
\hline & \multirow[t]{2}{*}{$\leq 32$} & Pop 1 (north) & 27 & 4 & 46 & 14 & 91 \\
\hline & & Pop 2 (south) & 25 & 0 & 29 & 4 & 58 \\
\hline & \multirow[t]{2}{*}{$\leq 29$} & Pop 1 (north) & 11 & 1 & 62 & 17 & 91 \\
\hline & & Pop 2 (south) & 12 & 0 & 42 & 4 & 58 \\
\hline & \multirow[t]{2}{*}{$\leq 26$} & Pop 1 (north) & 0 & 1 & 73 & 17 & 91 \\
\hline & & Pop 2 (south) & 3 & 0 & 51 & 4 & 58 \\
\hline \multirow{10}{*}{$\begin{array}{c}\geq 10 \\
\text { colonies } \\
(=100 \\
\text { CFU/ } \\
\text { ml })\end{array}$} & \multirow[t]{2}{*}{$\leq 37$} & Pop 1 (north) & 35 & 12 & 31 & 13 & 91 \\
\hline & & Pop 2 (south) & 23 & 2 & 27 & 6 & 58 \\
\hline & \multirow[t]{2}{*}{$\leq 34$} & Pop 1 (north) & 34 & 11 & 32 & 14 & 91 \\
\hline & & Pop 2 (south) & 23 & 2 & 27 & 6 & 58 \\
\hline & \multirow[t]{2}{*}{$\leq 32$} & Pop 1 (north) & 25 & 6 & 41 & 19 & 91 \\
\hline & & Pop 2 (south) & 23 & 2 & 27 & 6 & 58 \\
\hline & \multirow[t]{2}{*}{$\leq 29$} & Pop 1 (north) & 10 & 2 & 56 & 23 & 91 \\
\hline & & Pop 2 (south) & 10 & 2 & 40 & 6 & 58 \\
\hline & \multirow[t]{2}{*}{$\leq 26$} & Pop 1 (north) & 0 & 1 & 66 & 24 & 91 \\
\hline & & Pop 2 (south) & 2 & 1 & 48 & 7 & 58 \\
\hline
\end{tabular}

This article is protected by copyright. All rights reserved. 
Table 3. Posterior median and $95 \%$ posterior credibility interval (PCI) of true prevalence of CNS in milk (IMI) in the right hind quarter from 149 cows in 8 Danish dairy herds with AMS diagnosed by qPCR at different qPCR Ct-values cut-offs and BC at two CFU cut-offs

\begin{tabular}{|c|c|c|c|c|c|c|c|c|c|}
\hline \multirow{3}{*}{$\begin{array}{c}\text { BC } \\
\text { cutoff }\end{array}$} & \multirow[t]{3}{*}{ Parameter } & \multicolumn{8}{|c|}{ Test estimates at different qPCR cut-offs for IMI } \\
\hline & & \multicolumn{2}{|c|}{$\leq 37$} & \multicolumn{2}{|c|}{$\leq 34$} & \multicolumn{2}{|c|}{$\leq 32$} & \multicolumn{2}{|c|}{$\leq 29$} \\
\hline & & Med & $95 \% \mathrm{PCI}$ & Med & $95 \%$ PCI & Med & $95 \%$ PCI & Med & $95 \% \mathrm{PCI}$ \\
\hline$\geq 5$ & SeqPCR $^{1}$ & 0.94 & $0.84-1.00$ & 0.94 & $0.84-1.00$ & 0.90 & $0.78-0.99$ & 0.86 & $0.67-0.99$ \\
\hline colonies & $\mathrm{SeBC}^{2}$ & 0.67 & $0.53-0.90$ & 0.67 & $0.53-0.90$ & 0.67 & $0.54-0.88$ & 0.79 & $0.64-0.97$ \\
\hline$(=500$ & $\mathrm{SpqPCR}^{3}$ & 0.77 & $0.52-0.99$ & 0.77 & $0.52-0.99$ & 0.83 & $0.59-0.99$ & 0.90 & $0.75-1.00$ \\
\hline \multirow[t]{5}{*}{$\mathrm{CFU} / \mathrm{ml})$} & $\mathrm{SpBC}^{4}$ & 0.92 & $0.78-1.00$ & 0.92 & $0.78-1.00$ & 0.90 & $0.75-0.99$ & 0.85 & $0.72-0.98$ \\
\hline & Prevelance & 0.51 & $0.30-0.68$ & 0.51 & $0.30-0.68$ & 0.48 & $0.29-0.65$ & 0.35 & $0.20-0.53$ \\
\hline & Pop1 (north) & & & & & & & & \\
\hline & Prevelance & 0.79 & $0.54-0.93$ & 0.79 & $0.54-0.93$ & 0.78 & $0.53-0.93$ & 0.61 & $0.41-0.79$ \\
\hline & Pop2 (south) & & & & & & & & \\
\hline \multirow{8}{*}{$\begin{array}{c}\geq 10 \\
\text { colonies } \\
(=1000 \\
\text { CFU/ } \\
\mathrm{ml})\end{array}$} & SeqPCR & 0.96 & $0.86-1.00$ & 0.96 & $0.86-1.00$ & 0.91 & $0.79-0.99$ & 0.89 & $0.70-0.99$ \\
\hline & $\mathrm{SeBC}$ & 0.63 & $0.47-0.90$ & 0.63 & $0.47-0.90$ & 0.62 & $0.47-0.87$ & 0.76 & $0.58-0.97$ \\
\hline & SpqPCR & 0.69 & $0.47-0.97$ & 0.69 & $0.47-0.97$ & 0.78 & $0.55-0.98$ & 0.86 & 0.71-0.99 \\
\hline & $\mathrm{SpBC}$ & 0.94 & $0.82-1.00$ & 0.94 & $0.82-1.00$ & 0.93 & $0.80-1.00$ & 0.89 & 0.78-0.99 \\
\hline & Prevelance & 0.43 & $0.24-0.64$ & 0.43 & $0.24-0.64$ & 0.43 & $0.23-0.62$ & 0.30 & $0.15-0.48$ \\
\hline & Pop1 (north) & & & & & & & & \\
\hline & Prevelance & 0.75 & $0.48-0.90$ & 0.75 & $0.48-0.90$ & 0.75 & $0.48-0.92$ & 0.57 & $0.37-0.76$ \\
\hline & Pop2 (south) & & & & & & & & \\
\hline
\end{tabular}

${ }^{1} \mathrm{SeqPCR}=$ sensitivity of $\mathrm{qPCR} ;{ }^{2} \mathrm{SeBC}=$ sensitivity of culture $;{ }^{3} \mathrm{SpqPCR}=$ specificity of qPCR;

${ }^{4} \mathrm{SpBC}=$ specificity of culture

This article is protected by copyright. All rights reserved. 
Table 4. Posterior median and 95\% posterior credibility interval (PCI)) of true prevalence of CNS in teat skin colonization (TAC) in the right hind quarter from 149 cows in 8 Danish dairy herds with AMS diagnosed by qPCR at different qPCR Ct-values cut-offs, and BC at two CFU cut-offs

\begin{tabular}{|c|c|c|c|c|c|c|c|c|c|}
\hline \multirow[t]{3}{*}{ BC cutof } & \multirow[t]{3}{*}{ Parameter } & \multicolumn{8}{|c|}{ Test estimates at different qPCR cut-offs for TAC } \\
\hline & & \multicolumn{2}{|c|}{$\leq 37$} & \multicolumn{2}{|c|}{$\leq 34$} & \multicolumn{2}{|r|}{$\leq 32$} & \multicolumn{2}{|c|}{$\leq 29$} \\
\hline & & Med & $95 \%$ PCI & Med & $95 \%$ PCI & Med & $95 \%$ PCI & Med & $95 \%$ PCI \\
\hline$\geq 5$ & SeqPCR $^{1}$ & 0.48 & $0.15-0.81$ & 0.47 & $0.14-0.79$ & 0.36 & $0.04-0.76$ & 0.17 & $0.01-0.52$ \\
\hline colonies & $\mathrm{SeBC}^{2}$ & 0.85 & $0.27-0.99$ & 0.85 & $0.25-0.99$ & 0.83 & $0.24-1.00$ & 0.86 & $0.29-1.00$ \\
\hline$(=50$ & $\mathrm{SpqPCR}^{3}$ & 0.52 & $0.20-0.85$ & 0.53 & $0.21-0.86$ & 0.62 & $0.23-0.95$ & 0.84 & $0.49-0.99$ \\
\hline \multirow[t]{5}{*}{$\mathrm{CFU} / \mathrm{ml})$} & $\mathrm{SpBC}^{4}$ & 0.15 & $0.01-0.72$ & 0.15 & $0.01-0.75$ & 0.13 & $0.004-0.75$ & 0.15 & $0.01-0.69$ \\
\hline & Prevelance & 0.49 & $0.04-0.96$ & 0.51 & $0.05-0.95$ & 0.50 & $0.09-0.91$ & 0.49 & $0.05-0.95$ \\
\hline & Pop1 (north) & & & & & & & & \\
\hline & Prevelance & 0.49 & $0.01-0.99$ & 0.49 & $0.02-0.99$ & 0.47 & $0.02-0.98$ & 0.50 & $0.02-0.98$ \\
\hline & Pop2 (south) & & & & & & & & \\
\hline \multirow{3}{*}{$\begin{array}{c}\geq 10 \\
\text { colonies } \\
(=100 \\
\mathrm{CFU} /\end{array}$} & SeqPCR & 0.48 & $0.14-0.82$ & 0.47 & $0.12-0.80$ & 0.36 & $0.05-0.78$ & 0.17 & $0.02-0.51$ \\
\hline & $\mathrm{SeBC}$ & 0.77 & $0.21-0.98$ & 0.78 & $0.20-0.98$ & 0.76 & $0.19-0.99$ & 0.78 & $0.26-0.98$ \\
\hline & SpqPCR & 0.52 & $0.18-0.86$ & 0.53 & $0.20-0.86$ & 0.62 & $0.21-0.94$ & 0.84 & $0.47-0.98$ \\
\hline \multirow{4}{*}{$\mathrm{ml})$} & SpBC & 0.23 & $0.02-0.79$ & 0.23 & $0.02-0.81$ & 0.20 & $0.01-0.80$ & 0.23 & $0.02-0.74$ \\
\hline & Prevelance & 0.50 & $0.04-0.96$ & 0.50 & $0.04-0.95$ & 0.50 & $0.07-0.93$ & 0.50 & $0.04-0.97$ \\
\hline & Pop1 (north) & & & & & & & & \\
\hline & Prevelance & 0.50 & $0.02-0.98$ & 0.50 & $0.02-0.98$ & 0.48 & $0.03-0.97$ & 0.51 & $0.02-0.98$ \\
\hline & Pop2 (south) & & & & & & & & \\
\hline
\end{tabular}

${ }^{1} \mathrm{SeqPCR}=$ sensitivity of qPCR; ${ }^{2} \mathrm{SeBC}=$ sensitivity of culture; ${ }^{3} \mathrm{SpqPCR}=$ specificity of qPCR;

${ }^{4} \mathrm{SpBC}=$ specificity of culture

This article is protected by copyright. All rights reserved. 